\title{
STRATEGI PEMASARAN PAKET WISATA PT. UBS TOUR AND TRAVEL DI DENPASAR BALI
}

\author{
Herlita Br Tarigan \\ Ni Putu Eka Mahadewi \\ I Putu Sudana \\ Email : herlitatarigan@gmail.com \\ PS. S1 Industri Perjalanan Wisata \\ Fakultas Pariwisata UNUD
}

\begin{abstract}
ABSTRAK
PT. UBS Tour and Travel merupakan salah satu biro perjalanan wisata yang ada di Bali. Perusahaan ini mengalami fluktuasi dalam penjualan paket wisatanya dan mengalami persaingan yang semakin ketat antar Biro Perjalanan Wisata yang ada di Bali. Dengan permasalahan yang ada dalam perusahaan maka penelitian ini dilakukan untuk mengetahui strategi pemasaran dari PT. UBS Tour and Travel dan menganalisis lingkungan pemasaran serta membuat strategi dan program pemasaran yang dapat diterapkan di perusahaan tersebut.Teknik pengumpulan data yang dilakukan dengan cara observasi, wawancara, studi kepustakaan dan didukung dengan kusioner. Hasil data yang diperoleh dianalisa dengan deskriptif kualitatif yang dipadukan dengan analisis Skala Likert dan analisis SWOT.

Hasil dari penelitian ini adalah berdasarkan hasil analisis skala likert yang dilakukan terhadap lingkungan internal dan eksternal pada PT. UBS Tour and Travel dan dipadukan dengan analisis SWOT didapat suatu strategi pemasaran yang dapat diterapkan PT. UBS Tour and Travel yaitu (1) strategi penciptaan dan pengembangan produk wisata, (2) strategi peningkatan promosi, (3) strategi peningkatan sumber daya manusia, (4) strategi pengembangan segmentasi pasar, (5) strategi peningkatan produk dan jasa.

Saran yang dapat diberikan untuk PT. UBS Tour and Travel yaitu memperbaharui informasi tentang kemasan paket wisata yang menarik, tampilan website yang menarik, menyediakan sarana dan prasarana yang baik, mengkemas paket wisata dalam bentuk brosur yang lebih variatif, mempercepat proses pemesanan paket wisata dan kualitas pelayanan dari PT. UBS Tour and Travel yang selama ini sudah baik perlu dijaga dan ditingkatkan lagi.
\end{abstract}

\section{Kata Kunci : Strategi Pemasaran, Paket Wisata.}

\section{PENDAHULUAN}

Pariwisata merupakan salah satu sektor yang diandalkan pemerintah untuk memperoleh devisa. Bali merupakan salah satu daerah tujuan wisata utama di Indonesia. Sebagai daerah tujuan wisata utama di Indonesia, Bali mendapatkan perhatian dari pemerintah dalam mengembangkan pariwisata. Hal ini, dapat dilihat dari berkembang dan bertambahnya sarana dan prasarana pariwisata seperti akomodasi, transportasi, serta biro perjalanan wisata. Salah satu biro perjalanan wisata yang ada di Bali adalah PT. UBS Tour and Travel yang bergerak dalam bidang jasa, khususnya jasa perjalanan wisata. Berikut ini jumlah wisatawan yang menggunakan paket wisata PT. UBS Tour and Travel yang dapat dilihat pada Tabel 1.

Pada Tabel 1 dapat dilihat jumlah wisatawan yang menggunakan paket wisata PT. UBS Tour and Travel menggalami fluktasi sehingga berpengaruh terhadap hasil penjualan paket wisata di PT. UBS Tour and Travel yang dapat dilihat pada Tabel 2. 
Tabel 1. Jumlah Wisatawan yang Menggunakan Paket Wisata PT. UBS Tour and Travel pada Tahun 2010 - 2014

\begin{tabular}{|l|l|c|}
\hline Tahun & $\begin{array}{l}\text { Jumlah } \\
\text { wisatawan } \\
\text { (orang) }\end{array}$ & $\begin{array}{l}\text { Pertumbuhan } \\
(\%)\end{array}$ \\
\hline 2010 & 4.438 & - \\
\hline 2011 & 5.327 & 10 \\
\hline 2012 & 4.876 & $-4,5$ \\
\hline 2013 & 3.638 & $-12,7$ \\
\hline 2014 & 3.834 & 2,5 \\
\hline \multicolumn{2}{|l|}{ Rata - Rata Pertumbuhan } & $-1,17$ \\
\hline
\end{tabular}

Sumber : PT. UBS Tour and Travel 2015

Tabel 2. Hasil Penjualan paket wisata di PT. UBS Tour and Travel pada Tahun 2010 - 2014

\begin{tabular}{|l|l|c|}
\hline Tahun & $\begin{array}{l}\text { Hasil Penjualan } \\
(\mathrm{Rp})\end{array}$ & $\begin{array}{l}\text { Pertumbuhan } \\
(\%)\end{array}$ \\
\hline 2010 & 181.604 .000 & - \\
\hline 2011 & 143.362 .000 & $-10,53$ \\
\hline 2012 & 58.966 .000 & $-29,43$ \\
\hline 2013 & 93.966 .000 & 29,69 \\
\hline 2014 & 106.774 .000 & 6,81 \\
\hline \multicolumn{2}{|l|}{ Rata - rata Pertumbuhan } & $-0,86$ \\
\hline
\end{tabular}

Sumber : PT. UBS Tour and Travel 2015

Berdasarkan latar belakang di atas, maka yang menjadi rumusan masalah dalam penelitian ini adalah:

1. Apa yang menjadi kekuatan dan kelemahan dari faktor internal serta peluang dan ancaman dari faktor eksternal dari strategi pemasaran yang diterapkan oleh PT. UBS Tour and Travel?

2. Bagaimanakah strategi pemasaran yang diterapkan oleh PT. UBS Tour and Travel dalam memasarkan paket wisatanya?

3. Bagaimanakah strategi dan program pemasaran yang bisa diterapkan oleh PT. UBS Tour and Travel untuk meningkatkan penjualan paket wisata.

\section{METODE PENELITIAN}

Dalam penelitian ini analisis yang digunakan adalah analisis deskriptif kualitatif yaitu dengan menggunakan pendekatan SWOT dan kondisi bauran pemasaran atau marketing mix. Teknik pengumpulan data yang digunakan adalah observasi, wawancara, kuisioner, studi kepustakaan dan dokumentasi. Pengambilan sampel sebanyak 50 orang yang terdiri dari wisatawan yang menggunakan jasa PT. UBS Tour and Travel untuk analisis lingkungan internal dan 10 responden untuk analisis lingkungan eksternal.

\section{HASIL DAN PEMBAHASAN}

Persepsi Wisatawan terhadap Lingkungan Internal dan Pihak Manajemen terhadap Lingkungan Eksternal PT. UBS Tour and Travel

\section{Lingkungan Internal}

\begin{tabular}{|c|c|c|c|}
\hline \multicolumn{4}{|c|}{ Faktor Internal } \\
\hline No & Kekuatan (Strengths) & $\begin{array}{l}\text { Rata }- \\
\text { rata }\end{array}$ & Kategori \\
\hline 1 & $\begin{array}{l}\text { Variasi daya tarik wisata } \\
\text { yang dikunjungi dalam } \\
\text { paket wisata }\end{array}$ & 3,44 & Baik \\
\hline 2 & $\begin{array}{l}\text { Harga paket wisata yang } \\
\text { ditawarkan PT. UBS Tour } \\
\text { and Travel }\end{array}$ & 3 & Cukup Baik \\
\hline 3 & $\begin{array}{l}\text { Penyampaian informasi } \\
\text { objek wisata dari guide } \\
\text { kepada wisatawan }\end{array}$ & 3,34 & Baik \\
\hline 4 & $\begin{array}{l}\text { Kemampuan berbahasa } \\
\text { guide }\end{array}$ & 3,48 & Baik \\
\hline 5 & Seragam guide & 3,16 & Cukup Baik \\
\hline 6 & $\begin{array}{l}\text { Keramah - tamahan guide } \\
\text { saat melakukan tour }\end{array}$ & 3,66 & Baik \\
\hline 7 & $\begin{array}{l}\text { Kesesuaian kegiatan tour } \\
\text { dengan intinerary/jadwal } \\
\text { tour }\end{array}$ & 3,6 & Baik \\
\hline No & Kelemahan (Weakness) & $\begin{array}{l}\text { Rata }- \\
\text { rata }\end{array}$ & Kategori \\
\hline 1 & $\begin{array}{l}\text { Penyajian paket wisata } \\
\text { dalam bentuk brosur }\end{array}$ & 2,66 & Tidak Baik \\
\hline 2 & $\begin{array}{l}\text { Promosi lewat website } \\
\text { dari PT. UBS Tour and } \\
\text { Travel }\end{array}$ & 2,50 & Tidak Baik \\
\hline
\end{tabular}




\begin{tabular}{|l|l|l|l|}
\hline 3 & $\begin{array}{l}\text { Kebersihan transportasi } \\
\text { yang digunakan selama } \\
\text { melakukan tour }\end{array}$ & 2,44 & Tidak Baik \\
\hline 4 & $\begin{array}{l}\text { Proses pemesanan paket } \\
\text { wisata di PT. UBS Tour } \\
\text { and Travel }\end{array}$ & 2,54 & Tidak Baik \\
\hline
\end{tabular}

Sumber: Hasil Penelitian 2015

Berdasarkan persepsi wisatawan terhadap lingkungan internal dari PT. UBS Tour and Travel maka didapatkan indikator kekuatan yaitu variasi daya tarik wisata yang dikunjungi dalam paket wisata, harga paket wisata yang ditawarkan PT. UBS Tour and Travel, penyampaian informasi objek wisata dari guide kepada wisatawan, kemampuan berbahasa guide, seragam guide, keramah - tamahan guide saat melakukan tour, kesesuaian kegiatan tour dengan intinerary/jadwal tour. Sedangkan yang menjadi indikator kelemahan dari PT. UBS Tour and Travel adalah penyajian paket wisata dalam bentuk brosur, promosi lewat website dari PT. UBS Tour and Travel, kebersihan transportasi yang digunakan selama melakukan tour, proses pemesanan paket wisata di PT. UBS Tour and Travel.

\section{Lingkungan Eksternal}

\begin{tabular}{|c|c|c|c|}
\hline \multicolumn{4}{|c|}{ Faktor Eksternal } \\
\hline No & Peluang (Opportunities) & $\begin{array}{l}\text { Rata }- \\
\text { rata }\end{array}$ & Kategori \\
\hline 1 & $\begin{array}{lr}\text { Kemajuan } & \text { teknologi } \\
\text { informasi } & \text { seperti } \\
\text { penggunaan } & \text { sistem } \\
\text { internet } & \text { dalam } \\
\text { memasarkan } & \text { paket } \\
\text { wisata } & \\
\end{array}$ & 4,3 & $\begin{array}{l}\text { Sangat } \\
\text { Baik }\end{array}$ \\
\hline 2 & $\begin{array}{l}\text { Kemajuan transportasi } \\
\text { udara seperti murahnya } \\
\text { tarif tiket pesawat }\end{array}$ & 4,1 & Baik \\
\hline 3 & $\begin{array}{l}\text { Kemajuan prasarana di } \\
\text { Bali }\end{array}$ & 4,2 & Baik \\
\hline 4 & $\begin{array}{l}\text { Kondusifnya situasi } \\
\text { keamanan di Bali }\end{array}$ & 4,7 & $\begin{array}{l}\text { Sangat } \\
\text { Baik }\end{array}$ \\
\hline 5 & $\begin{array}{l}\text { Budaya masyarakat di } \\
\text { Bali yang mendukung } \\
\text { atau menjadi daya tarik } \\
\text { kegiatan pariwisata }\end{array}$ & 4,7 & $\begin{array}{l}\text { Sangat } \\
\text { Baik }\end{array}$ \\
\hline No & Ancaman (Threats) & $\begin{array}{l}\text { Rata - } \\
\text { rata }\end{array}$ & Kategori \\
\hline 1 & 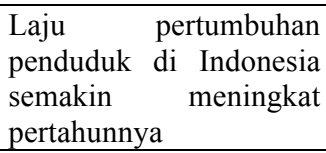 & 2,1 & Tidak Baik \\
\hline
\end{tabular}

\begin{tabular}{|l|l|l|l|}
\hline 2 & Krisis ekonomi global & 1,3 & $\begin{array}{l}\text { Sangat } \\
\text { Tidak Baik }\end{array}$ \\
\hline 3 & $\begin{array}{l}\text { Naiknya harga BBM } \\
\text { (Bahan Bakar Minyak) }\end{array}$ & 1 & $\begin{array}{l}\text { Sangat } \\
\text { Tidak Baik }\end{array}$ \\
\hline 4 & $\begin{array}{l}\text { Nilai tukar mata uang } \\
\text { rupiah yang melemah }\end{array}$ & 1,8 & Tidak Baik \\
\hline 5 & $\begin{array}{l}\text { Tingkat bencana alam di } \\
\text { Indonesia }\end{array}$ & 1,8 & Tidak Baik \\
\hline
\end{tabular}

Sumber: Hasil Penelitian 2015

Berdasarkan persepsi pihak manajemen PT. UBS Tour and Travel, ASITA, HPI yang menjadi indikator peluang adalah kemajuan teknologi informasi seperti penggunaan internet dalam memasarkan paket wisata, kemajuan transportasi udara seperti murahnya tarif tiket pesawat, kemajuan prasarana di Bali, kondusifnya situasi keamanan Bali, budaya masyarakat di Bali yang mendukung atau menjadi daya tarik kegiatan pariwisata. Sedangkan yang menjadi indikator ancaman adalah laju pertumbuhan penduduk di Indonesia semakin meningkat pertahunnya, krisis ekonomi global, naiknya harga BBM (Bahan Bakar Minyak), nilai tukar mata uang rupiah yang melemah, tingkat bencana alam di Indonesia.

Analisis Kekuatan (Strengths), Kelemahan (Weakness), Peluang (Opportunities) dan Ancaman (Threats) pada PT. UBS Tour and Travel

Berdasarkan analisis SWOT ditemukan strategi pemasaran dan program pemasaran yang dapat diterapkan PT. UBS Tour and Travel sebagai berikut:

1) Strategi Strengths Opportunities (SO) adalah strategi yang memanfaatkan kekuatan atas peluang yang telah diidentifikasi. Strategi yang dapat diterapkan dalam memasarkan paket wisata PT. UBS Tour and Travel adalah strategi penciptaan dan pengembangan produk wisata.

2) Strategi Weakness Opportunities (WO) adalah strategi yang meminimalkan kelemahan dengan berusaha memanfaatkan peluang yang ada. Strategi yang dapat diterapkan dalam memasarkan paket wisata PT. UBS Tour and Travel adalah strategi 
peningkatan promosi dan strategi peningkatan sumber daya manusia.

3) Strategi Strengths Threats (ST) adalah strategi yang memanfaatkan kekuatan yang dimiliki untuk mengurangi ancaman. Strategi yang dapat diterapkan dalam memasarkan paket wisata PT. UBS Tour and Travel adalah strategi pengembangan segmentasi pasar.

Strategi Weakness Threats (WT) adalah strategi bertahan dengan meminimalisir kelemahan dengan menghindari ancaman. Strategi yang dapat diterapkan dalam memasarkan paket wisata PT. UBS Tour and Travel adalah strategi pertahankan kualitas produk dan jasa.

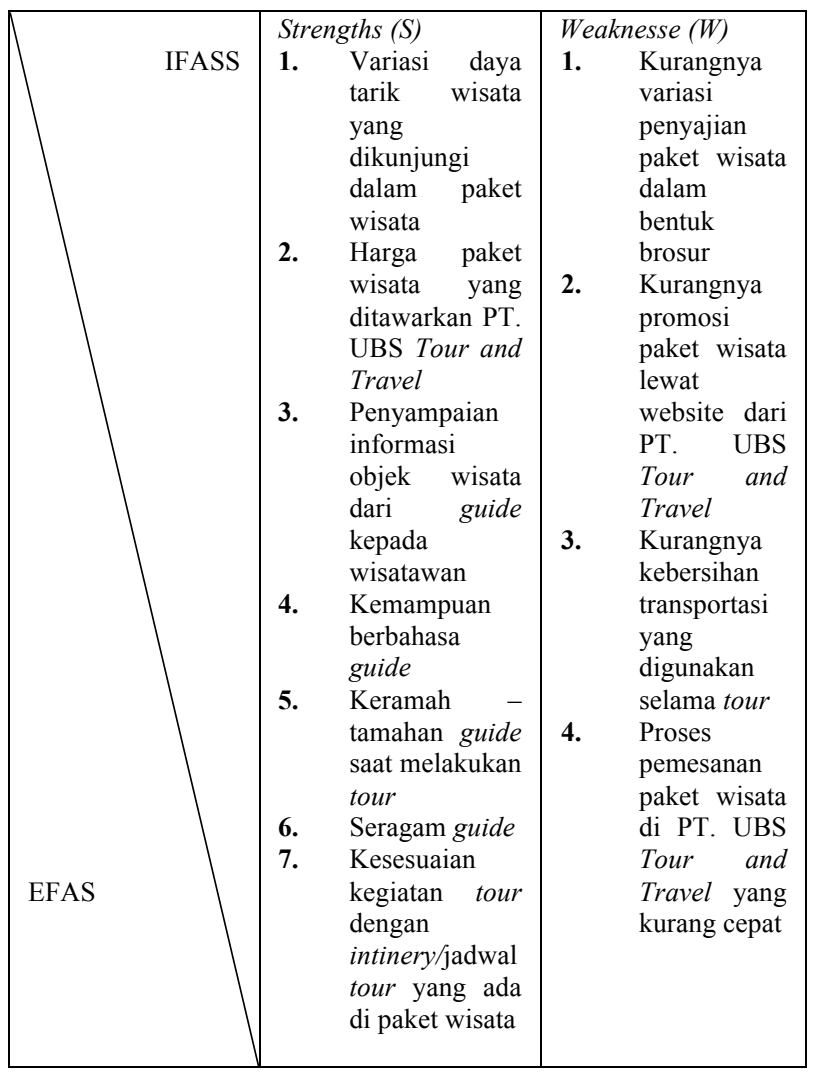

\begin{tabular}{|c|c|c|}
\hline \begin{tabular}{ll}
\multicolumn{2}{l}{ Opportunity $(O)$} \\
a) & Kemajuan \\
& teknologi \\
informasi & seperti \\
penggunaan & sistem \\
internet & dalam \\
memasarkan & paket wisata \\
Kemajuan \\
transportasi \\
udara seperti \\
murahnya \\
tarif tiket \\
pesawat \\
Kemajuan \\
prasarana di \\
Bali \\
Kondusifnya \\
keamanan di \\
Bali \\
Budaya \\
masyarakat \\
di Bali yang \\
mendukung/ \\
menjadi daya \\
tarik \\
kegiatan \\
pariwisata
\end{tabular} & $\begin{array}{l}\text { Strategi SO } \\
\text { (Strenghts } \\
\text { Opportunities) } \\
\text { 1. } \\
\text { Strategi } \\
\text { penciptaan dan } \\
\text { pengembangan } \\
\text { produk wisata } \\
\text { (kombinasi } \\
\text { antara } \\
1,2,3,4,5,6,7 \\
\text { dan a,b,c,d,e) }\end{array}$ & 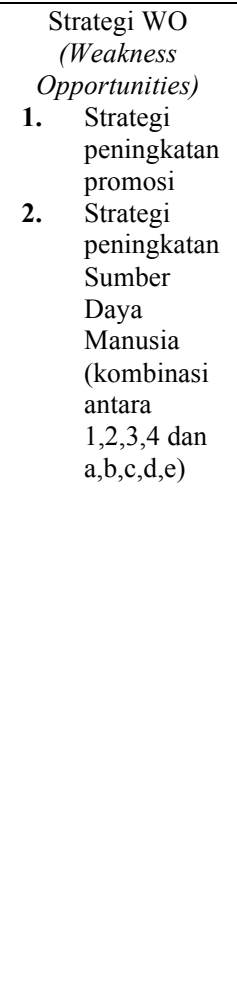 \\
\hline \begin{tabular}{ll}
\multicolumn{3}{l}{ Threats $(T)$} \\
a) & Laju \\
& pertumbuhan \\
& penduduk di \\
& Indonesia \\
& semakin \\
& meningkat \\
& pertahunnya \\
b) & Krisis \\
& ekonomi \\
& global \\
c) & Naiknya \\
& harga BBM \\
& (Bahan \\
& Bakar \\
& Minyak) \\
d) Nilai tukar & mata uang \\
& rupiah yang \\
melemah & Tingkat \\
bencana \\
alam di \\
Indonesia
\end{tabular} & \begin{tabular}{ll}
\multicolumn{2}{c}{ Strategi ST } \\
(Strenghts Threats) \\
1. & Strategi \\
& pengembangan \\
& segmentasi \\
& pasar \\
& (kombinasi \\
& antara \\
& $1,2,3,4,5,6,7$ \\
& dan a,b,c,d,e)
\end{tabular} & 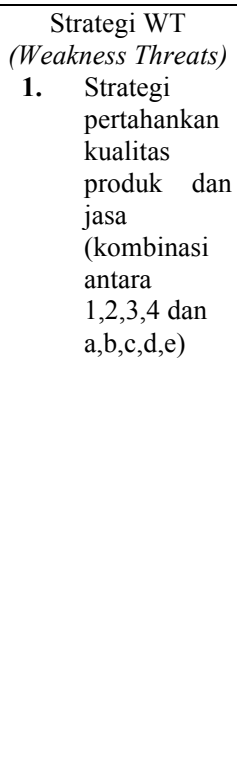 \\
\hline
\end{tabular}

Sumber: Hasil Penelitian 2015 
SIMPULAN DAN SARAN

Simpulan

Berdasarkan latar belakang dan pembahasan di atas maka dapat disimpulkan sebagai berikut.

1. Berdasarkan persepsi wisatawan terhadap lingkungan internal dan persepsi manajemen PT. UBS Tour and Travel, ASITA, HPI terhadap lingkungan eksternal maka, didapatkan indikator kekuatan, kelemahan, peluang dan ancaman.

2. Strategi dan program pemasaran yang dapat diterapkan di PT. UBS Tour and Travel yaitu:

a) Strategi Strengths Opportunities (SO) strategi yang menghasilkan strategi penciptaan dan pengembangan produk wisata yang terdiri atas menciptakan produk wisata yang inovatif yaitu produk wisata yang belum pernah ada sebelumnya, menciptakan dan mengembangkan produk wisata MICE (Meeting, Incentive, Convention dan Exibhition), membuat paket wisata dengan minat khusus, dan membuat beberapa kemasan paket wisata dengan harga terjangkau dan menarik.

b) Strategi Weakness Opportunities (WO) adalah strategi peningkatan promosi dan strategi peningkatan sumber daya manusia yang terdiri atas program meningkatkan promosi lewat website, memperbaiki pemasaran lewat brosur, meningkatkan kerjasama dengan biro perjalanan wisata baik yang di dalam negeri maupun di luar negeri, dan bekerja sama dengan maskapai penerbangan untuk promosi harga termurah serta bisa menjadi agen resmi dari maskapai penerbangan tersebut, meningkatkan pelayanan kualitas sumber daya manusia dengan mengadakan pelatihan kepada karyawan, melakukan meeting secara berkala, dan membuat acara rekreasi setahun sekali bersama staf.

c) Strategi Strengths Threats (ST) adalah strategi pengembangan segmentasi pasar yang terdiri atas program menambah pangsa pasar terhadap wisatawan Eropa, Australia, dan melaukan segmentasi pasar di dalam negeri.

d) Strategi Weakness Threats (WT) adalah strategi peningkatan kualitas produk dan jasa yang terdiri atas program meningkatkan kualitas produk dari segi kualitas pelayanan seperti peningkatan kualitas transportasi yang digunakan, menyiapkan variasi website, meningkatkan produk kemasan paket wisata yang lebih beragam, memberikan potongan harga kepada wisatawan yang membeli paket wisata dalam jumlah banyak, dan memilih agent - agent yang diajak bekerjasama yang dapat memberikan kontribusi yang maksimal kepada wisatawan.

\section{Saran}

Hal yang dapat disarankan kepada PT. UBS Tour and Travel yaitu:

a. Mengkemas penyajian paket wisata dalam bentuk brosur yang lebih variatif sehingga membuat wisatawan tertarik untuk membaca brosur tersebut dan otomatis dapat menjadi media promosi paket wisata PT. UBS Tour and Travel

b. Memaksimalkan promosi paket wisata lewat website dan selalu memperbaruhi informasi tentang kemasan paket wisata yang menarik dengan memberikan variasi warna ciri khas yang menarik dari website perusahaan dan website yang mudah di askes wisatawan.

c. Memberikan sarana dan prasarana yang baik sehingga memberikan kesan yang kurang baik bagi wisatawan.

d. Meningkatkan pelayanan khususnya dalam proses pemesanan paket wisata sehingga wisatawan merasa puas dengan proses pemesanan yang cepat.

e. Kualitas pelayanan yang selama ini sudah baik perlu dijaga dan ditingkatkan lagi agar wisatawan dapat puas dan membuat citra yang baik bagi perusahaan sehingga membuat 
hubungan kerjasama yang baik dengan wisatawan, overseas agent, dan perusahaan pariwisata lainnya.

f. Mengganti agent - agent yang diajak bekerjasama dalam paket wisata yang dianggap tidak memberikan kontribusi yang maksimal kepada wisatawan sehingga tidak akan memberikan kesan negative kepada PT. UBS Tour and Travel.

\section{DAFTAR PUSTAKA}

Kotler, Philip dan Armstrong Gary. 2002. Prinsip - prinsip Pemasaran. Jakarta :PT.Erlangga
Koetjaraningrat. 1993. Metodologi Penelitian dalam Bidang Kepariwisataan. Jakarta: PT. Gramedia Pustaka Utama

Rangkuti, Freddy. 2002. Analisis SWOT Teknik Membedah Kasus Bisnis. Jakarta: Gramedia Pustaka Utama.

Soekadijo, R. G. 2000. Anatomi Pariwisata. Jakarta: Gramedia.

Suyitno. 2001. Perencanaan Wisata. Yogyakarta: Liberty

Yoeti, Oka A. 1993. Pemasaran Pariwisata. Bandung: Angkasa Bandung. 